\title{
Leveraging agricultural total factor productivity growth for productive, sustainable and resilient farming systems
}

\author{
Oliver T. Coomes ${ }^{1}$, Bradford L. Barham ${ }^{2}$, Graham K. MacDonald ${ }^{1}$, \\ Navin Ramankutty ${ }^{3}$, and Jean-Paul Chavas ${ }^{1}$
}

Re-revised manuscript submitted to: Nature Sustainability

Length: ca. 5400 words (with references)

October 25, 2018

Affiliations:

1. Department of Geography, McGill University, Burnside Hall Rm 705, 805 Sherbrooke St. West, Montreal, QC, Canada H3A 0B9

2. Department of Agricultural and Applied Economics, University of Wisconsin-Madison, 427 Lorch St. Madison, WI USA 53706

3. UBC School of Public Policy and Global Affairs and Institute for Resources, Environment and Sustainability, The University of British Columbia, 6476 NW Marine Drive, Vancouver, BC, Canada V6T $1 \mathrm{Z2}$.

https://doi.org/10.1038/s41893-018-0200-3

Coomes, O. T., Barham, B. L., MacDonald, G. K., Ramankutty, N. \& Chavas, J.-P. Leveraging total factor productivity growth for sustainable and resilient farming. Nature Sustainability 2, 22-28 (2019). 


\begin{abstract}
Increased global agricultural output since the 1990s has been largely driven by innovations that raised the use efficiency of labor, land, capital and other inputs - referred to as total factor productivity (TFP) growth. Yet, debates over the future of farming still weigh heavily on models of agricultural land use and socioecological tradeoffs along traditional (partial-factor productivity) growth paths of 'intensification' or 'extensification'. Overlooking the role of TFP in the evolution of global agriculture not only obscures the changing drivers of productivity growth but misses vital linkages with agricultural sustainability and farming system resilience. We describe two pathways for growth-technology-based and ecosystembased-and link these in a heuristic framework that emphasizes sustainability and resilience outcomes in farming systems. Interdisciplinary research is urgently needed to empirically examine the dynamic interplay of TFP growth, farming system sustainability and resilience. Such insights are needed to transform TFP growth as metric into actionable efforts on farms and beyond.
\end{abstract}

\title{
1. Introduction
}

Meeting the food demands of a growing and increasingly affluent global population while simultaneously promoting more sustainable agriculture is a grand challenge for humanity [1,2]. During much of the $20^{\text {th }}$ century, agricultural producers kept pace with demand either by bringing new lands into production (extensification) or by increasing the use of labor, machinery, energy, fertilizer, and other inputs to raise yields (intensification). The consequences of extensification and intensification pathways are well understood, including biodiversity loss, greenhouse gas emissions, and soil and water quality degradation [3-6].

Debates over the future of farming systems and agriculture continue to focus heavily on the socioecological tradeoffs along extensification or intensification pathways for growth. Examples include extensive 'wildlife friendly' farming to promote biodiversity or 'sustainable' intensification to reduce the pressures of agriculture on tropical forests and other critical ecosystems [7-9]. And yet, most growth in global agricultural output since the 1990s has come not from intensification or extensification but from more efficient use of labor, land, capital and inputs that boost the total factor productivity (TFP) of agriculture $[10,11]$.

In high-income countries, growth in TFP has been strong enough since the 1980s to sustain rising agricultural output with significant reductions in agricultural input use (Figure 1a). This trend suggests that focusing more on the role of TFP growth-essentially, doing 'more with less' - has the potential to be a game-changer in agricultural sustainability and the future of global farming. Indeed, a focus on TFP growth challenges the false dichotomy that productive agriculture is unsustainable and sustainable agriculture is unproductive. In theory, TFP growth could encourage synergies needed to bolster food production with fewer negative environmental externalities and more positive feedbacks to ecosystem services. Could this synergy also extend to enhancing the resilience of farming systems to external stressors, such as drought, disease, and market volatility? In practice, we do not know. There is a paucity of empirical research on the actual tradeoffs or synergies across these outcomes.

One explanation for our dearth of understanding arises from how we measure TFP. Typically, we compare at a national level the ratio of total output to a cost-share weighted 'basket' of marketed inputs, assuming constant returns to scale. Growth in TFP occurs when changes in management practices and technology yield more output with the same or fewer market inputs. As a result, the role of ecosystem services, let alone feedbacks to the sustainability of their natural production systems, are not included in standard TFP calculations (e.g., $[10,11])$, in part because most natural capital and ecosystem service contributions to agriculture are not 'marketed'. 
Because standard TFP measures omit important environmental and social outcomes, they cannot address the implications for sustainability or resilience of efficiency gains and output growth [12]. Sustainable and resilient farming systems can be drivers of TFP growth, but TFP growth can also be a pathway toward sustainable and resilient farming systems (Box 1). Both sustainability and resilience interact with the dynamics of productivity $[13,14]$, aspects that are often ignored in TFP assessments of agro-ecosystems. Sustainability issues arise when productivity declines over time (e.g., when soil erosion reduces land productivity). Resilience issues arise when adverse shocks to an agro-ecosystem have lasting negative impacts on productivity and farm viability. Sustained gains in agricultural productivity depend fundamentally on inputs of natural capital and ecosystem services in farming systems. Efforts to expand the measure of TFP growth recognize the limitations of a growth-only focus in agricultural development policy but tend to fall short of explicitly detailing the linkages among TFP growth, sustainability and resilience. Such linkages are particularly important in the context of climate change impacts on crop productivity [15].

Promising research advances at the farm and sector level are linking technological change and TFP outcomes to environmental impacts, such as greenhouse gas emissions intensity on farms [16]. The OECD's green growth accounting framework describes the concept of total resource productivity (TRP), which includes non-market environmental goods and ecosystem services in an "environmentallyadjusted" TFP [12]. Chambers [17] assesses agricultural TFP in the presence of by-products, such as environmental damages associated with pesticide use. However, these new approaches do not provide sufficient spatial and commodity coverage and resolution, or (in most cases) the empirical depth needed to examine the dynamic interplay of sustainability and resilience outcomes with TFP changes in agriculture. Further inquiry is essential to improve farm systems management and public policy design that builds synergies in the agricultural sector by targeting productivity, sustainable and resilience.

\section{The role of TFP in driving global agricultural productivity}

Over the past 60 years, global agricultural output grew by $2-2.5 \%$ per annum with the primary driver initially being input intensification $[10,18,19]$. The global shift toward TFP growth became evident in the industrialized countries in the 1970s and in developing countries, especially Brazil and China, in the 1990 s and 2000s $[11,20]$. Agricultural TFP growth has also been associated with changes in relative resource use, as technological change has typically been "biased": labor-saving, sometimes land-saving, but also fertilizer-using and pesticide-using [21,22]. Innovations have often been responsive to resource scarcity, e.g., labor-saving mechanization that reduces labor demand under rising wages, or the development of new varieties that are fertilizer-using when fertilizer prices are low. Technological change has also affected output mix. Most farms are multi-output enterprises reflecting synergies among crops as well as between crops and livestock (e.g., [23]). Yet, agriculture has seen a general trend toward greater farm specialization, reflecting in part differential rates of productivity growth across outputs. Rapid productivity growth in corn or broiler chickens, for example, has stimulated farmers to become more specialized in these products. This trend raises questions about possible tradeoffs between agricultural productivity, ecosystem functions and biodiversity [24].

Agricultural intensification during the Green Revolution contributed between one-half and threequarters of output growth during the 1960s-80s (Figure 1b), largely attributable to improved seeds combined with more fertilizer, chemical inputs, and water [25]. During this period, area expansion added less than $20 \%$ of output growth. By comparison, more efficient input use in the 1990 s and 2000s contributed about three-quarters to growth in comparison to less than $10 \%$ from input intensification (Figure 1b). These TFP gains correspond with modern advances in genetic and genomic science that (in 
the case of genetically modified crops) allowed farmers to reduce inputs of pesticides, herbicides and labor based on enhanced plant resistance. By providing additional options for weed control, biotechnology has affected tillage practices and contributed to reducing energy and herbicide use in US agriculture [22]. Interestingly, more of the underlying productivity gains in agriculture since the 1990s appear to have occurred in agricultural sectors outside of 'grains' (see $[10,11]$ ) including livestock $[26,27]$. The ability to better decompose TFP as a metric to understand which sectors are experiencing productivity gains, as well as the drivers of those gains would provide insights as to how innovation could translate to different nutritional value of food supplies nationally and globally [28-30].

National TFP measures not only typically omit dynamic feedbacks to sustainability and resilience outcomes, they also rely on inference or more literally 'residuals' from aggregate national level data rather than direct observation of farm activity. This makes it problematic to pinpoint the specific drivers at different scales - from farm to the regional economy. Identifying sources of TFP growth and their potential for resource savings is a critical first step to understanding whether and how these gains are likely to enhance (or reduce) agricultural sustainability and resilience.

In Figure 2, we draw on existing research to posit that TFP growth arises from technological and ecosystem-based approaches that interact through farm-system management. The technological approach includes at least four major sources of TFP growth:

(1) the gene revolution (e.g., selective breeding, transgenesis, and CRISPR genome-editing);

(2) hardware and data (e.g., drones, robotics, automation, and sensor technology);

(3) enhanced input delivery/precision farming; and,

(4) post-harvest management on farms that reduce losses (e.g., improved storage facilities, transportation, and market information).

Innovation and adoption in these areas can generate significant savings in terms of inputs, labor, and capital, and natural resources. If supported by land use planning and policies to avoid new land clearing, such productivity gains could in turn affect the sustainability and resilience of farming systems. For example, GMO crops and precision agriculture may impose new costs (e.g., higher seed cost and application cost) but can result in net input savings, including reduced herbicide, pesticide, seed, fertilizer, fuel and energy. On-farm automation, information and data management systems reduce the time needed by farmers to run the farm. Improved storage and market information on prices, qualities, and transportation/distribution opportunities can encourage larger actual harvests and improved efforts to store and haul for sale.

Ecosystem-based approaches offer complementary sources of TFP growth that arise through the reliance on and maintenance of ecosystem services and biodiversity in agricultural production [31], including:

(1) pollinator management;

(2) biological pest control;

(3) integrated crop-livestock practices; and,

(4) rotation \& soil conservation.

While pollination and pest control are ecosystems services to agriculture, integrated crop-livestock and rotations represent farm system management that enhances related ecosystem services both on- and off-farm (e.g., erosion control and nutrient cycling) [32] and therefore potentially TFP. For example, no 
tillage and rotational grazing can reduce environmental impacts and result in labor savings. Rotational grazing also results in capital savings by reducing the need for holding sheds and farm equipment. Management practices, such as crop rotation and drip irrigation, save on natural resources by conserving the quality and quantity of land and water used. The choice and implications for sustainability and resilience of drawing more heavily on technological or ecosystem-based approaches to TFP growth is context dependent and requires more research to identify the specific tradeoffs entailed.

\section{TFP growth for sustainable and resilient farming systems}

A key goal of sustainable farming is to maintain or enhance productivity while minimizing social and environmental externalities both on farms and across agricultural landscapes (Box 1). Despite impressive gains in agriculture in the $20^{\text {th }}$ century the dominant pathways of productivity growth-including massive growth in reactive nitrogen use and land system change-may have ultimately served to undercut the long-term sustainability of agriculture [33]. Agricultural productivity and the value of food depend critically on the sustainable use of ecosystem services and biodiversity, including crop pollination and pest regulation [34,35]. Indeed, a more holistic accounting of the "true" cost of food would require us to fully incorporate the environmental and other externalities associated with the drive for higher productivity [36].

Resilience describes the capacity of systems to withstand adverse shocks and to recover quickly from their effects while maintaining their essential characteristics $[37,38]$. In farming systems, many of these shocks, such as drought or disease outbreaks, are difficult to anticipate which highlights the need for adaptive capacity to enhance resilience at the farm and landscape scale and to reduce systemic shocks that could undermine food security at larger scales. The role of resilience and the assessment and adaptation to shocks are becoming more crucial in the face of climate change and more globally interconnected food systems. To the extent that food price spikes (driven by a confluence of factors, including extreme weather) have led to political instability and social unrest around the world $[39,40]$, the challenge of both pursuing higher yields and maintaining their stability is a critical balancing act for public policy and agricultural producers. Understanding the links between TFP growth and farming system resilience therefore emphasizes the need to evaluate risk exposure and management strategies in agriculture at multiple scales.

More explicit analysis of the links between TFP growth and the sustainability and resilience of farming systems at the landscape scale would help to guide new pathways toward synergistic, locally-relevant solutions (Figure 2). The landscape offers an intermediary unit of analysis between the agroecosystem and the region in which to assess the long-term capacity for agricultural production and human wellbeing [41]. We argue that further attention should be directed to the role of landscape processes in TFP growth outcomes, including the potential for spatially explicit externalities and interactions among nearby farms that could accelerate farm system changes [42]. In general, sources of TFP growth beget significant savings at the farm-level which give rise to an array of TFP growth-related farming outcomes, ranging from higher planting densities and crop yields to lower water and energy use. These farming outcomes can in turn feedback to influence the landscape. For example, precision application that applies information technology to monitoring of soil and crop conditions can help farmers to reduce fertilizer and pesticide use, thereby reducing environmental pollution and contamination and enhancing the prospect for agricultural sustainability at the farm and landscape scales [43,44]. Lower input costs may increase farm resilience to economic and environmental shocks especially for small-scale farmers in developing countries. Use of crop rotations or genetically modified (GM) crops can improve productivity 
by enhancing the resistance to biotic or abiotic stressors [45]-highlighting the potential synergies and substitutability among sources of TFP growth.

Farm-level links between TFP growth and sustainability or resilience outcomes can arise through both direct and indirect channels. No-tillage systems, for example, conserve not only soil and water but also labor invested, which can affect sustainability and resilience indirectly as farmers use the freed-up time to better manage waste or conserve water elsewhere on the farm. Dynamic land-use feedbacks, at the farm through landscape level, also shape sustainability and resilience outcomes associated with management practices and accordingly TFP growth. Water quality outcomes, for example, for agricultural and non-agricultural users depend on how many dairy farmers adopt riparian buffer strips and where and how they do so - across space and over extended time horizons. Lewis et al. [42] explore these types of feedbacks in the Andes (e.g., irrigation and high biodiversity potatoes) and the US (e.g., organic versus conventional practices), providing a framework that explains spatial clustering of agricultural systems that can elucidate farm-landscape interactions for TFP, sustainability, and resilience.

Figure 2 offers a framework for assessing how key sources of TFP growth may link to outcomes at the farm and landscape scale, including plausible feedbacks-either positive or negative-for resilience and sustainability. Our assessment of these linkages suggests three key considerations for navigating the sustainability and resilience dimensions of TFP growth (Table 1).

First, significant positive outcomes for sustainability and resilience arise from farm-level resource savings, but TFP growth is not a sufficient condition for socially or environmentally desirable outcomes. For example, GM crops beget significant savings in inputs and promise conservation benefits as well as reduced vulnerability to pest and disease in the short-run but may increase pressure to use marginal lands that may be unsustainable in the long-run. GM crops may also raise vulnerability to the development of genetic resistance developing [46], which could eventually reduce resilience. In terms of equity, GM seeds may be more expensive, raising issues of access to intellectual property for smallholder farmers in low-income countries [47]. Similarly, labor productivity arising from TFP growth will benefit farmers, but potentially at the detriment to the livelihoods of farm laborers who need to seek alternate employment [48].

Second, TFP growth may enhance sustainability but not necessarily the resilience of farming systems, and vice versa. Drought-tolerant GM crops can help farmers, especially in predominantly rain-fed areas, to withstand water shortages and grow more food [49]. This could enhance the capacity of these systems to adapt to drought while simultaneously weakening aspects of sustainability, for example, by increasing the use of fertilizers and other chemical inputs associated with the production of higher value crops in environmentally sensitive locations. Likewise, changes in crop mix-particularly a trend toward growing concentration of production in a small number of cereal and oil crops globally-could affect the resilience of crops to pests and pathogens [28].

Third, landscape effects are important and could reduce the synergies of TFP for sustainability. Based on historic yield and harvested area trends associated with agricultural intensification, it is not clear whether future yield increases due to innovation would be likely to reduce or increase cropland area in specific regions, or globally (e.g., [50,51]). As with the drought-tolerant GM crop example, rising returns from more efficient agricultural technologies and management practices could drive the incorporation of more marginal and fragile lands into production, resulting in further land clearing for this new production ('leakage'). Still, directionality outcomes are subtle. Specialization resulting from TFP growth, where specific crops are better matched to land and soil types through enhanced land-allocation, has 
uncertain implications for landscape diversity, depending on the biophysical environment, farming system type, and cost-price conditions. In more homogenous landscapes, for example, specialization can increase mono-cropping over large areas that reduce agrobiodiversity and potentially resilience of farming systems. Conversely, in regions with diverse soils specialization could result in greater field heterogeneity and resilience of farming systems.

Much work remains to deepen our understanding of the drivers of TFP growth and in turn their implications for sustainability and resilience of farming systems. This work will require attention to the interplay of farm and landscape levels with spatial and temporal feedbacks incorporated. It will also require deep system-level engagement of natural and social scientists to understand farmer behavior, agricultural and ecological processes, and the potential for both synergies and tradeoffs associated with efforts to integrate TFP growth with positive sustainability and resilience-building outcomes.

\section{Five priorities for agricultural productivity research}

Improved efficiency has become the primary driver of gains in agricultural output growth. It is time that research and development efforts in international agriculture expand beyond, on one hand, the current focus on the impacts of intensification/extensification and, on the other, on TFP growth without explicit incorporation of the contribution of natural capital and ecosystem services to increased agricultural productivity. At the nexus of agricultural productivity, sustainability and resilience lie an array of research themes that merit much closer study. We identify five priorities.

1. Decompose the drivers of TFP growth and their implications for sustainable farming. What is the relative contribution of each driver in Table 1 at the farm-level and beyond the farm gate? How TFP growth occurs is important for several reasons. First, as highlighted in the technical capacity and TFP literature [52], global variation in TFP growth reflects significant national and regional differences in social investment in knowledge, infrastructure, institutional change, extension services and commercialization for their development and diffusion. Thus, TFP growth does not just 'fall out of the sky'. It originates from ongoing private and public efforts to advance the productivity of agriculture. A better understanding of the various sources will inform how to promote specific types of TFP growth with an eye to sustainability, resilience and social equity. Since considerably more research effort has focussed on the technological approaches to TFP growth compared to ecosystem-based approaches, disentangling whether technology-based or ecosystem-based approaches have been (and will be) more important to sustainable growth is critical.

2. Attribute TFP growth to specific actions and their interactions across scales. Because most TFP measures are 'recovered' or inferred from national output and input data, it is inherently difficult to identify and attribute the specific sources of TFP expansion at the farm level. Attribution requires the construction of long-term panel datasets on both experimental and private farms in order to connect macro-level TFP phenomena with specific changes occurring at farm and/or regional levels. This too requires public-private cooperation and further scientific investigation, and it is a serious undertaking. Research efforts will need to capture the potential for TFP gains to arise at levels beyond the farm, such as information provision and post-harvest management (Figure 2), and for complex non-linear feedbacks that might arise within and between human and natural processes at different scales across agricultural landscapes.

3. Incorporate feedbacks and interactions between technology-based and ecosystem-based approaches to TFP growth. How do distinct sources of TFP on-farm and at the regional scale relate to sustainability and resilience outcomes? Fundamental gains will involve better specification of how the different 
sources of TFP growth highlighted in Figure 2 shape sustainability and resilience outcomes across actual landscapes. Valuable precedents for this type of research are evident in bioenergy systems [53], perennial cropping systems [54], and labor utilization $[55,56]$. This requires attention to farm-level heterogeneity in terms of farming systems, size, tenancy and crop type or livestock.

4. Assess scale-dependency in TFP gains. What biases operate through TFP gains on farm size - across the distribution from small family farms to large farm enterprises - that may influence the sustainability and resilience of farming systems? A recent study by Rada and Fuglie [57] indicates that TFP growth often originates among small holders and TFP growth technologies - which often bring constant returns to scale - are not necessarily biased against them. Pushing the boundaries of TFP research to consider the linkages between farm size, TPF and sustainability will require integrative efforts by social and natural scientists, examining dynamics of TFP growth at multiple spatial scales, from farming system to globally.

5. Consider temporal mismatches between TFP growth and ecosystem service outcomes. Does TFP growth foster path dependency in agricultural systems through, for example, sunk costs, making them more 'brittle' and less capable of coping with shocks and secular change? Temporal mismatches inherent in the relationship between agricultural productivity growth and its impacts on other ecosystem services stress the need to incorporate temporal dynamics in TFP analysis [58]. For example, time-lags can range from months to decades between the introduction of agricultural best management practices and measurable effects on water quality [57]. Bias in TFP measures themselves can arise from failing to account for improvements or deterioration in future production potential, similar to GDP measures that do not incorporate the depletion of natural resource bases.

\section{Conclusion}

Much more is needed in the drive for greater agricultural productivity than better measures of TFP. Research is required to measure explicitly both sources of TFP growth and their implications for the environment (on and beyond farms) and food supplies (including the nutritional quality of food). The potential for synergies between TFP growth and sustainability and resilience outcomes seems high because in one way or another TFP promises more outputs for less material inputs. The main challenge though is similar to that in 'intensification': gains in productivity could push new land and resources into production à la Jevon's paradox. Thus, TFP gains need to be weighed against societal consideration of the broader value for ecosystem services, biodiversity, food security, and social equity. This calls for the will to use policies, such as taxes, subsidies, and regulations to pursue the best combinations of technological gains in agriculture and broader societal goals. The extent to which 'win-win-win' synergies between agricultural productivity growth, farming system sustainability and resilience are possible could hold great potential for identifying and building on positive synergies between agricultural development, the environment and society in this century.

\section{Acknowledgements}

The authors express their gratitude to Associate Editor, Dr. William Burnside, and three anonymous reviewers for their careful reading of our manuscript, their insightful comments, and most helpful suggestions.

\section{References}

1. Godfray, H.C.J., Beddington, J.R., Crute, I.R., Haddad, L., Lawrence, D., Muir, J.F., Pretty, J., Robinson, S., Thomas, S.M. and Toulmin, C. 2010. "Food security: the challenge of feeding 9 billion people" Science 327: 812-818. 
2. Springmann, M., Clark, M., Mason-D'Croz, D., Wiebe, K., Bodirsky, B.L., Lassaletta, L., de Vries, W., Vermeulen, S.J., Herrero, M., Carlson, K.M., Jonell, M., Troell, M., DeClerk, F., Gordon, L.J., Zurayk, R., Scarborough, P., Rayner, M., Loken, B., Fanzo, J., Godfray, H.C.J, Tilman, D., Rockström, J. and Willett, W. 2018. "Options for keeping the food system within environmental limits" Nature, https://doi.org/10.1038/s41586-018-0594-0

3. Matson, P.A., Parton, W.J., Power, A.G. and Swift, M.J., 1997. "Agricultural intensification and ecosystem properties" Science 277: 504-509.

4. Tilman, D., Cassman, K.G., Matson, P.A., Naylor, R. and Polasky, S., 2002. “Agricultural sustainability and intensive production practices" Nature 418(6898): 671-677.

5. Foley, J.A., DeFries, R., Asner, G.P., Barford, C., Bonan, G., Carpenter, S.R., Chapin, F.S., Coe, M.T., Daily, G.C., Gibbs, H.K. and Helkowski, J.H. 2005. "Global consequences of land use" Science 309(5734): 570-574.

6. West, P.C., Gerber, J.S., Engstrom, P.M., Mueller, N.D., Brauman, K.A., Carlson, K.M., Cassidy, E.S., Johnston, M., MacDonald, G.K., Ray, D.K. and Siebert, S. 2014. "Leverage points for improving global food security and the environment" Science 345: 325-328.

7. Tscharntke, T., Clough, Y., Wanger, T.C., Jackson, L., Motzke, I., Perfecto, I., Vandermeer, J. and Whitbread, A., 2012. "Global food security, biodiversity conservation and the future of agricultural intensification" Biological Conservation 151: 53-59.

8. Garnett, T., Appleby, M.C., Balmford, A., Bateman, I.J., Benton, T.G., Bloomer, P., Burlingame, B., Dawkins, M., Dolan, L., Fraser, D. and Herrero, M. 2013. "Sustainable intensification in agriculture: premises and policies" Science 341: 33-34.

9. Rockström, J., Williams, J., Daily, G., Noble, A., Matthews, N., Gordon, L., Wetterstrand, H., DeClerck, F., Shah, M., Steduto, P. and de Fraiture, C., 2017. "Sustainable intensification of agriculture for human prosperity and global sustainability" Ambio 46: 4-17.

10. Fuglie, K. 2012. "Productivity growth and technology capital in the global agricultural economy," in Productivity Growth in Agriculture: An International Perspective, K. Fuglie, S.L. Wang, and V.E. Ball, eds. Wallingford, UK: CAB International.

11. Fuglie, K. 2015. "Accounting for growth in global agriculture", Bio-based and Applied Economics 4(3): 201-234.

12. Fuglie, K., Benton, T., Sheng, Y., Hardelin, J., Mondelaers K. and Laborde D. 2016. Metrics of Sustainable Agricultural Productivity. G20 MACS White Paper.

13. Chavas, J.P. 2015. "Dynamics, viability and resilience in bioeconomics" Annual Review of Resource Economics 7: 209-231.

14. Chavas, J.P. 2018. "Agro-ecosystem productivity and the dynamic response to shocks" in The Economics of Poverty Traps. (Barrett, C.B., M.R. Carter and J.P. Chavas, Eds.). University of Chicago Press, Chicago.

15. Lobell, D.B., Burke, M.B., Tebaldi, C., Mastrandrea, M.D., Falcon, W.P. and Naylor, R.L. 2008. "Prioritizing climate change adaptation needs for food security in 2030" Science. 319: 607-610.

16. Baldoni, E., Coderoni, S. and Esposti, R., 2017. "The productivity and environment nexus with farmlevel data. The case of carbon footprint in Lombardy FADN farms" Bio-based and Applied Economics, 6: 119-137.

17. Chambers, R. 2016. "Thinking about agricultural productivity accounting in the presence of byproducts," WP 16-02, Department of Agricultural and Resource Economics, University of Maryland.

18. Gollin, D. 2010. "Agricultural productivity and economic growth" Handbook of Agricultural Economics, Vol 4. Chapter 73: 3825-3866, Elsevier.

19. Headey, D., Alauddin, M. and Rao, D.S.P. 2010. "Explaining agricultural productivity growth: an international perspective" Agricultural Economics 41: 1-14. 
20. Fuglie, K.O. and S.L. Wang. 2013. "New evidence points to robust but uneven productivity growth in global agriculture", Global Journal of Emerging Market Economies 5(1) 23-30.

21. Binswanger, H.P. 1974. "The measurement of technical change biases with many factors of production" American Economic Review 64(6): 964-976.

22. Chavas, J.P., G. Shi, R. Nehring and K. Stiegert. 2018. "The effects of biotechnology on productivity and input demands in U.S. agriculture" Journal of Agricultural and Applied Economics 50: 387407.

23. Chavas, J.P. and M. Aliber. 1993. "An analysis of economic efficiency in agriculture: a nonparametric approach" Journal of Agricultural and Resource Economics 18:1-16.

24. Klasen, S., K.M. Meyer, C. Dislich, M. Euler, H. Faust, M. Gatto, et al. 2016. "Economic and ecological trade-offs of agricultural specialization at different spatial scales" Ecological Economics 122: 111-1120.

25. Evenson, R.E. and Gollin, D. 2003. "Assessing the impact of the Green Revolution, 1960 to 2000 " Science 300: 758-762.

26. Avila, A. and Evenson, R. 2010. "Total factor productivity growth in agriculture: The role of technology capital" In: Pingali, P. and Evenson, R. (eds.) Handbook of Agricultural Economics, 4. Elsevier, Amsterdam, pp. 3769-3822.

27. Nin, A., Arndt, C., Hertel, T., and Preckel, P. 2003. "Bridging the gap between partial and total factor productivity measures using direction distance functions" American Journal of Agricultural and Applied Economics 85: 928-42.

28. Khoury, C.K., Bjorkman, A.D., Dempewolf, H., Ramirez-Villegas, J., Guarino, L., Jarvis, A., Rieseberg, L.H. and Struik, P.C., 2014. "Increasing homogeneity in global food supplies and the implications for food security" Proceedings of the National Academy of Sciences 111: 4001-4006.

29. Pingali, P., 2015. "Agricultural policy and nutrition outcomes-getting beyond the preoccupation with staple grains" Food Security 7(3): 583-591.

30. DeFries, R., Fanzo, J., Remans, R., Palm, C., Wood, S. and Anderman, T.L., 2015. "Metrics for landscarce agriculture" Science 349(6245): 238-240.

31. DeClerck, F.A., Jones, S.K., Attwood, S., Bossio, D., Girvetz, E., Chaplin-Kramer, B., Enfors, E., Fremier, A.K., Gordon, L.J., Kizito, F. and Noriega, I.L., 2016. "Agricultural ecosystems and their services: the vanguard of sustainability?" Current Opinion in Environmental Sustainability 23: 92-99.

32. Power, A.G., 2010. "Ecosystem services and agriculture: tradeoffs and synergies" Philosophical Transactions of the Royal Society of London B: Biological Sciences, 365: 2959-2971.

33. Campbell, B., Beare, D., Bennett, E., Hall-Spencer, J., Ingram, J., Jaramillo, F., Ortiz, R., Ramankutty, N., Sayer, J. and Shindell, D., 2017. "Agriculture production as a major driver of the Earth system exceeding planetary boundaries" Ecology and Society, 22(4).

34. Bennett, E., Carpenter, S., Gordon, L., Ramankutty, N., Balvanera, P., Campbell, B., Cramer, W., Foley, J., Folke, C., Karlberg, L. and Liu, J., 2014. "Toward a more resilient agriculture" Solutions 5: 6575.

35. Chavas, J.P. 2017. "On food security and the economic valuation of food" Food Policy 69: 58-67.

36. The Economics of Ecosystems and Biodiversity (TEEB) (2018). Measuring what matters in agriculture and food systems: a synthesis of the results and recommendations of TEEB for Agriculture and Food's Scientific and Economic Foundations report. Geneva: UN Environment.

37. Walker, B., Holling, C.S., Carpenter, S. and Kinzig, A., 2004. "Resilience, adaptability and transformability in social-ecological systems" Ecology and Society 9(2).

38. Folke, C., 2006. "Resilience: The emergence of a perspective for social-ecological systems analyses" Global Environmental Change 16: 253-267.

39. Headey, D.M. 2011. "Rethinking the global food crisis: The role of trade shocks" Food Policy 36: 136146. 
40. Bellemare, M. 2015. "Rising food prices, food price volatility, and social unrest" American Journal of Agricultural Economics, 97(1): 1-21.

41. Wu, J., 2013. "Landscape sustainability science: ecosystem services and human well-being in changing landscapes" Landscape Ecology 28: 999-1023.

42. Lewis, D.J., Barham, B.L., and Zimmerer, K. 2008. "Spatial externalities in agriculture: empirical analysis, statistical identification, and policy implications" World Development, 36(10): 18131829.

43. Bongiovanni, R. and Lowenberg-DeBoer, J., 2004. "Precision agriculture and sustainability" Precision Agriculture 5(4): 359-387.

44. Aubert, B.A., Schroeder, A. and Grimaudo, J., 2012. "IT as enabler of sustainable farming: an empirical analysis of farmers' adoption decision of precision agriculture technology" Decision Support Systems 54(1): 510-520.

45. Shi, G., Chavas, J.P. and Lauer, J. 2013. "Commercialized transgenic traits, maize productivity and yield risk" Nature Biotechnology 31: 111-114.

46. Gilbert, N. 2013. "A hard look at GM crops" Nature 497(7447), 24-26.

47. Jacobsen, S.E., Sørensen, M., Pedersen, S.M. and Weiner, J., 2013. "Feeding the world: genetically modified crops versus agricultural biodiversity" Agronomy for Sustainable Development 33: 651662.

48. Hazell, P.B., 2005. "Is there a future for small farms?" Agricultural Economics, 32(s1): 93-101.

49. National Academies of Sciences, Engineering, and Medicine. 2016. Genetically Engineered Crops: Experiences and Prospects. Washington, DC: The National Academies Press.

50. Rudel, T.K., Schneider, L., Uriarte, M., Turner, B.L., DeFries, R., Lawrence, D., Geoghegan, J., Hecht, S., Ickowitz, A., Lambin, E.F. and Birkenholtz, T., 2009. "Agricultural intensification and changes in cultivated areas, 1970-2005" Proceedings of the National Academy of Sciences 106: 2067520680.

51. Hertel, T.W., Ramankutty, N., and Baldosa, U.L.C. 2014. "Global market integration increases likelihood that a future African Green Revolution could increase crop land use and CO2 emissions" Proceedings of the National Academy of Sciences 111(38): 13799-13804.

52. Fuglie, K., Wang, S.L. and Ball, V.E. eds. 2012. Productivity Growth in Agriculture: An International Perspective. Wallingford, UK: CAB International.

53. Robertson, P.G., Hamilton, S.K., Barham, B.L., Dale, B.E., Izaurralde, R.C., Jackson, R.D., Landis, D.A. Swinton, S.M., Thelen, K.D., and Tiedje, J.M. 2017. "Cellulosic biofuel contributions to a sustainable energy future: choices and outcomes" Science eeal2324, 30 June 2017.

54. Cox, T.S., Glover, J.D., Van Tassel, D.L., Cox, C.M. and DeHaan, L.R., 2006. "Prospects for developing perennial grain crops" Bioscience 56: 649-659.

55. Murgai, R., Ali, M. and Byerlee, D. 2001. "Productivity growth and sustainability in post-Green Revolution agriculture: the case of the Indian and Pakistan Punjabs" The World Bank Research Observer 16(2): 199-218.

56. Rada, N.E. and K.O. Fuglie, 2018. "New perspectives on farm size and productivity", Food Policy (in press). https://doi.org/10.1016/j.foodpol.2018.03.015

57. Ruben, R. 2005. "Smallholder farming in less-favoured areas: options for pro-poor and sustainable livelihoods" Wageningen University, Wageningen, Netherlands.

58. Liu, J., Dietz, T., Carpenter, S.R., Folke, C., Alberti, M., Redman, C.L., Schneider, S.H., Ostrom, E., Pell, A.N., Lubchenco, J. and Taylor, W.W., 2007. "Coupled human and natural systems" Ambio 36: 639-649.

59. Meals, D.W., Dressing, S.A. and Davenport, T.E., 2009. "Lag time in water quality response to best management practices: a review" Journal of Environmental Quality 39: 85-96. 
Box 1. Defining links between TFP, sustainability, and resilience.

Total factor productivity (TFP): a broad agricultural productivity metric that accounts for the contributions of all inputs to production, calculated as a ratio of total agricultural outputs (crop and animal products) to total inputs (land, labor, capital, and resource inputs) (Fuglie 2015), where outputs and inputs are typically aggregated on a monetary unit basis. TFP growth occurs when total agricultural output grows faster than inputs. TFP can be contrasted with partial factor productivity (PFP)-including indices such as crop yield, which focus on individual factors of production, such as land area.

Sustainable agriculture and TFP: we define sustainable agriculture as that which conserves vital ecosystem services to farming systems that support long-term agricultural production while simultaneously maintaining and enhancing human well-being at different scales by minimizing impacts on non-farm ecosystem services (sensu Wu 2013). A tenet of sustainable development (Brundtland definition) is to meet the needs of the present without compromising the capacity of future generations to meet their needs. Therefore, while the capacity for sustained agricultural productivity growth is important, the ability for future generations to prioritize agricultural development pathways should also be considered. The implications of TFP growth pathways for social equity, environmental quality, and economic viability at local to global scales are key considerations.

Resilient agriculture and TFP: resilient farming systems are able to adapt and cope with shocks or other external pressures while maintaining their essential structure and functions. With respect to TFP, resilient farming systems have sustained capacity to transform, learn, and innovate despite uncertainties and surprises (sensu Folke [38]). Key resilience considerations include the role of integrated feedback loops and cross-scale interactions in fostering adaptive capacity to withstand disturbances. In building farming system resilience through TFP, it is important to identify the key stressors affecting productivity (i.e., resilience 'of what to what'?) and social equity dimensions (i.e., whose resilience is being addressed?).

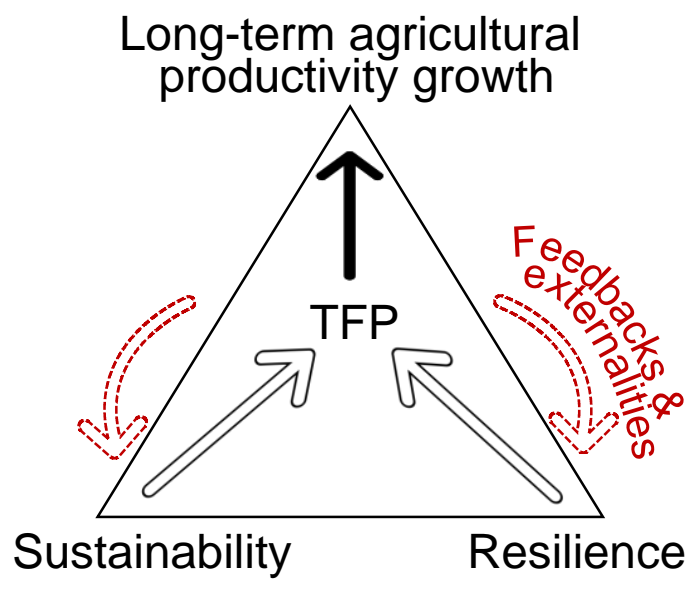

Box figure 1: Essential links between long-term agricultural productivity, sustainability, and resilience. TFP can be enhanced by beneficial links to sustainability and resilience (sustainability and resilience enhance TFP growth) but farming system management also influences natural capital and ecosystem services at the farm and landscape scale through feedbacks or externalities (TFP growth pathways affect sustainability and resilience). 
Figure 1. Agricultural output growth over time. Trends in agricultural inputs, agricultural outputs, and total factor productivity (TFP) over the period 1961-2014 for twenty-three high-income countries (a) and breakdown of the sources of global average annual output growth (typically $2-2.5 \%$ per annum) by decade (b). In (b), we classify one source of agricultural output growth (change in agricultural land area) as "extensification" and combine two other sources (the change in the share of cropland that is irrigated and the growth in inputs per hectare of agricultural land) as "intensification". Data used in (a) and (b) were obtained from the USDA Economic Research Service in July 2018 (https://www.ers.usda.gov/dataproducts/international-agricultural-productivity/).
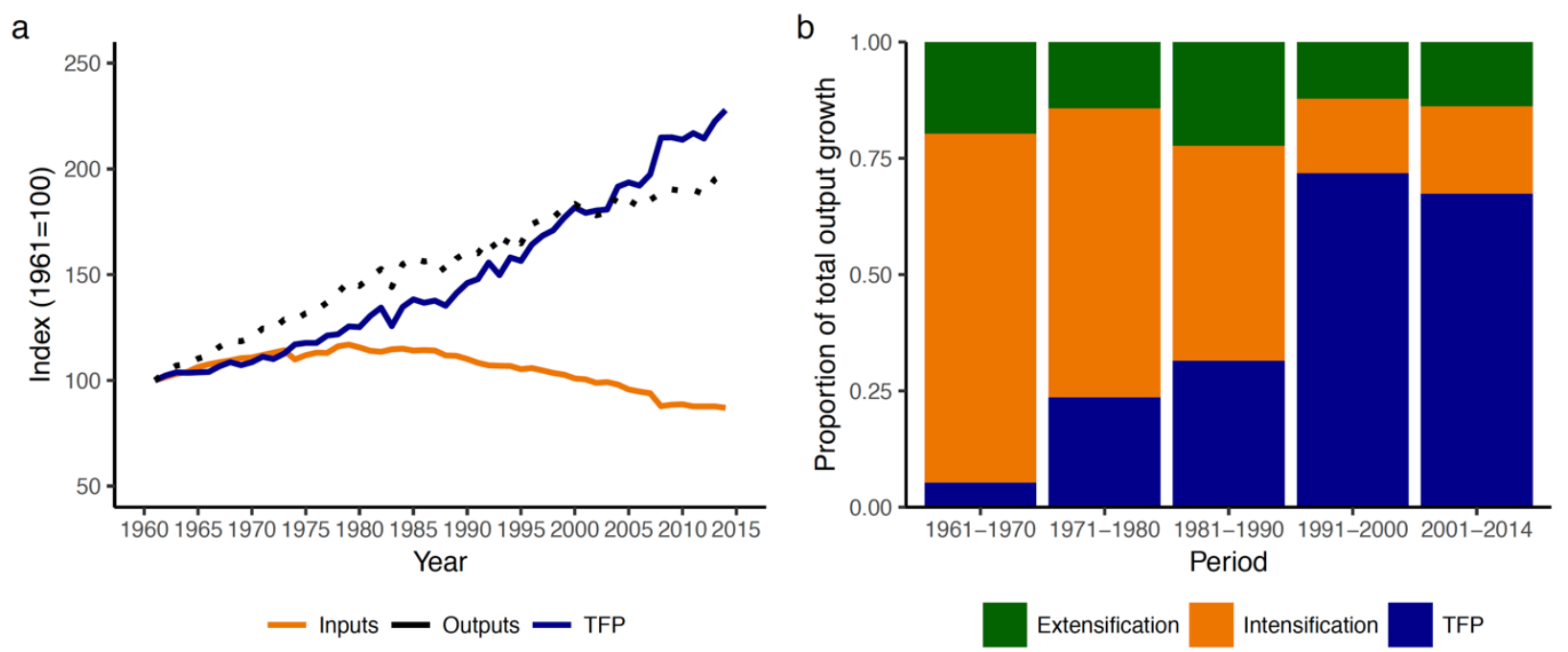
Figure 2. Heuristic framework for assessing sources of TFP growth. Technological innovation and ecosystem services are key input to TFP growth starting at the farm and landscape scales but with contributions from larger scales. Farm system management interacts with both technological and ecosystem-based approaches. TFP growth can be contrasted with traditional growth pathways that are focused more on partial factor productivity (i.e., area expansion and input intensification). TFP growth pathways can promote sustainability and resilience, for example, by reducing reliance on conventional inputs (fertilizer, water, and pesticides) to increase agricultural output. When feedbacks from any growth pathway degrade ecosystem services to agriculture (e.g., pollination and biological pest control), ecosystem-based approaches to TFP growth will be undermined.

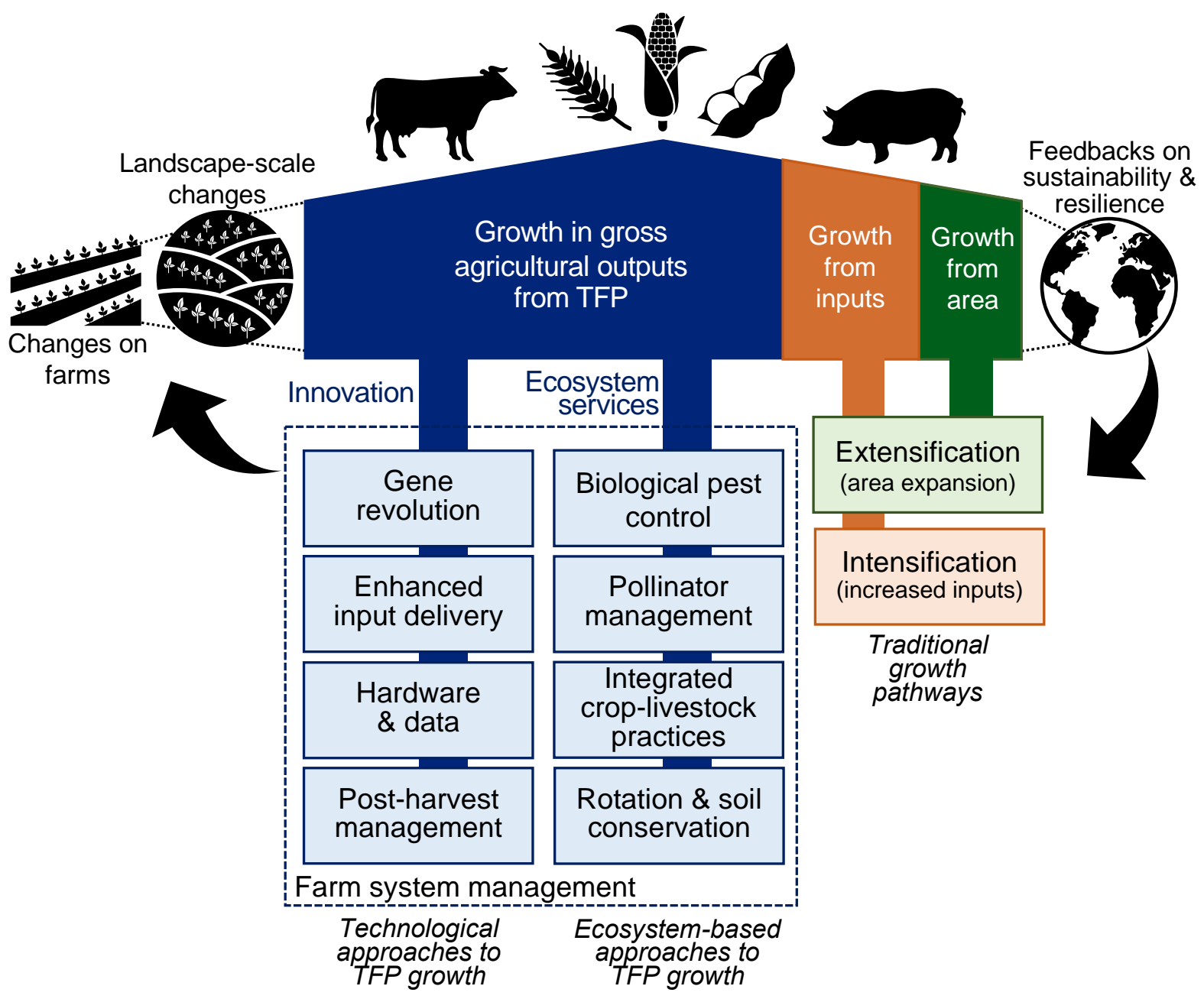


Table 1. Overview of key technological and ecosystem-based sources of TFP growth with consideration of hypothetical sustainability and resilience outcomes at the farm and landscape scales.

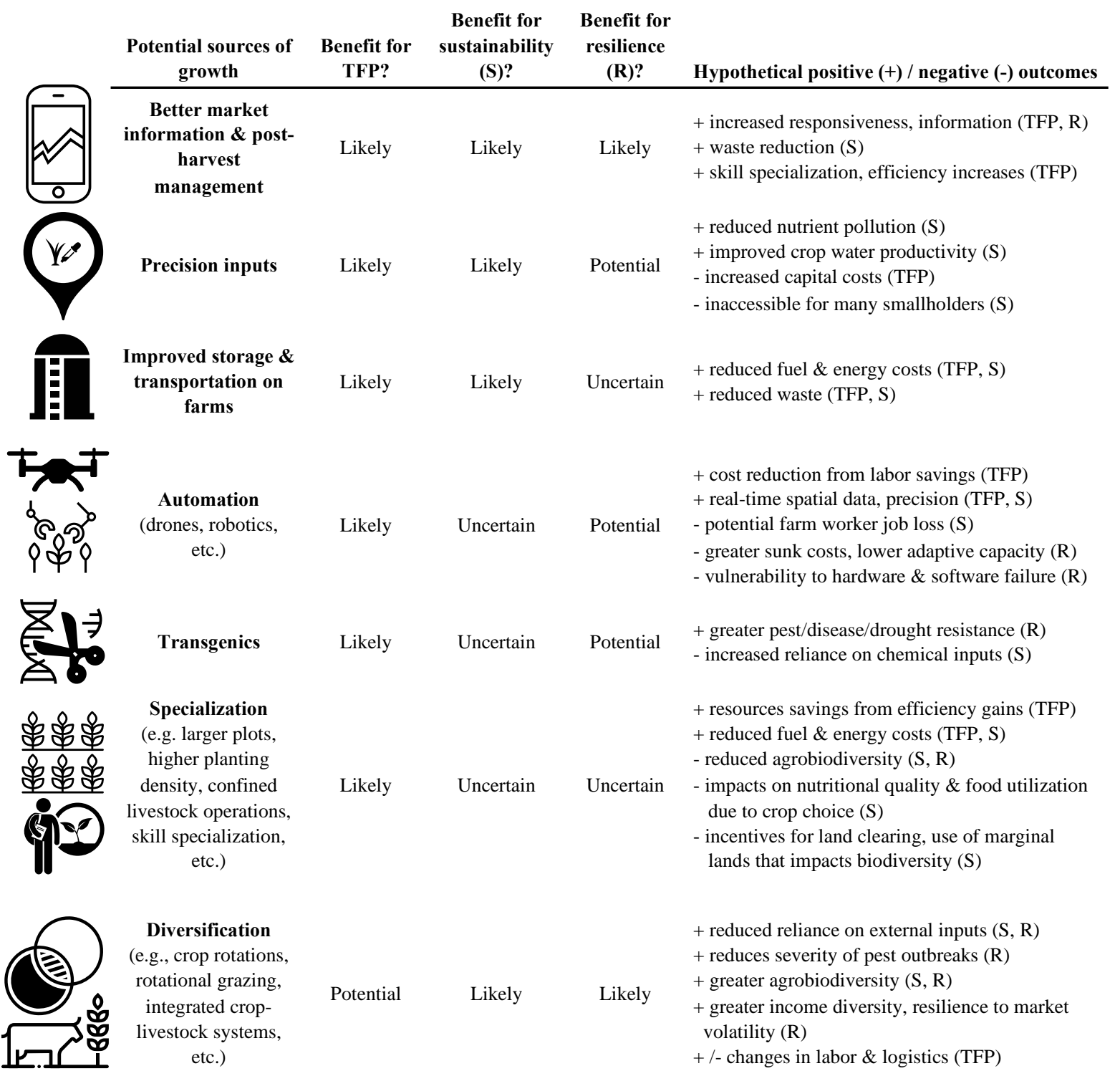

